\title{
КОНЦЕПЦІЯ ВІЙСЬКОВОЇ ЛОГІСТИКИ: ВІД ЗАРОДЖЕННЯ ДО СУЧАСНОГО ТРАКТУВАННЯ В ЗБРОЙНИХ СИЛАХ УКРАЇНИ
}

\author{
Т. М. Остащенко, О. П. Шматенко², М. В. Білоус², О. В. Галан², Д. В. Дроздов² \\ ${ }^{1}$ Командування Медичних сил Збройних Сил України, м. Київ, Украӥна \\ гукраїнська військово-медична академія, м. Київ, Україна
}

Вступ. На сьогодні подальший напрямок розвитку України спрямований на євроатлантичну інтеграцію. Відповідно до Державної програми реформування та розвитку Збройних Сил України на період до 2020 р., було створено єдину систему логістики та удосконалено систему медичного забезпечення Збройних Сил Украӥни відповідно до стандартів НАТО. Крім того, здійснено передачу певних функцій медичного постачання до системи логістики Збройних Сил України. Таким чином, питання військової логістики на сьогодні є актуальними для Медичних сил Збройних Сил України.

Мета. Проведення аналізу існуючих підходів до трактування терміну “військова логістика" в історичному аспекті та дослідження ї̈ сутності у відповідності до сучасних умов функціонування Медичних сил Збройних Сил України.

Матеріали та методи. Для досягнення мети дослідження проведено аналіз закордонної і вітчизняної наукової літератури та чинної нормативно-правової бази України. Методами дослідження $\epsilon$ інформаційний пошук, порівняння, систематизація, аналіз та синтез.

Результати. На основі проведеного аналізу, встановлено, що термін "військова логістика" досі перебуває в постійному розвитку і в певні історичні періоди в нього вкладався різний зміст. У процесі еволюції наукових підходів ведення військових дій, формувалася і військова логістика. Виникали нові логістичні системи, застосовувалися інноваційні методи та інструменти логістичної підтримки збройних сил. Ухронологічному порядку наведено кілька визначень терміну “військова логістика". 3'ясовано, що деякі автори, використовуючи різну термінологію, розглядають однакову суть або явище цієї категорії. Це свідчить про приналежність дослідника до різних логістичних шкіл чи акцентування його уваги на окремих сторонах логістичного процесу або системи в цілому.

Висновки. На підставі проведеного аналізу існуючих підходів до трактування терміну "військова логістика" в історичному аспекті встановлено, що концепція військової логістики є важливою складовою у плануванні і здійсненні переміщення, забезпечення життєдіяльності військ (сил) у мирний час і особливий період, а також невід'ємною частиною підтримки військових операцій. Досліджено сутність концепції військової логістики у відповідності до сучасних умов функціонування Медичних сил Збройних Сил України. Визначено необхідність у формуванні єдиного логістичного підходу до забезпечення Збройних Сил України медичною технікою і майном, з урахуванням закріплених у законодавстві правових норм щодо обігу лікарських засобів і медичних виробів та дозвільної системи у сфері фармацевтичної діяльності. Обгрунтовано доцільність у створенні єдиної ефективної системи управління медичним постачанням Збройних Сил України, враховуючи логістичний підхід, під єдиним керівництвом Командувача Медичних сил Збройних Сил України. Зазначено, що інтеграція головних констант військової логістики, як у систему військової охорони здоров'я в цілому, так і в їі фармацевтичний сектор обумовила створення військовофармацевтичної логістики у складі медичної логістики Збройних Сил України.

Ключові слова: військова логістика, Медичні сили Збройних Сил України.

Вступ. На сьогодні подальший напрямок розвитку України спрямований на євроатлантичну інтеграцію, який закріплено змінами до Конституції України щодо стратегічного курсу держави на набуття повноправного членства України в Європейському Союзі й в Організації Північноатлантичного договору та рішенням Ради національної безпеки і оборони України від 20 серпня 2021 р. “Про Стратегічний оборонний бюлетень України”. Відповідно до Державної програми реформування та розвитку Збройних Сил України на період до 2020 р., було створено єдину ефективну систему логістики та удосконалено систему медичного забезпечення ЗС України відповідно до стандартів НАТО. Крім того, здійснено передачу певних функцій медичного постачання до системи логістики Збройних Сил України. Таким чином, питання військової логістики на сьогодні $\epsilon$ актуальними для Медичних сил Збройних Сил України.

Військова логістика залишається предметом численних досліджень, як вітчизняних, так і зарубіжних вчених. Вивчення та узагальнення великої кількості зарубіжної літератури надає можливість виокремити три категорії літературних джерел 3 військової 
логістики. Перша категорія включає історичні звіти про війни та військові операції, розглянуті 3 точки зору логістики. Одна 3 перших книг цієї категорії - Мартіна Ван Кревельда (Martin van Creveld), яка вийшла ще у 1977 р. [1], науковий інтерес також викликає робота Роберта Керлі (Robert Curley) [2]. Цей клас історичних монографій надає характеристику етапів історичного розвитку військової логістики від ії̈ зародження, детальні описи логістичних процесів та подій у минулих війнах, а також деякі аналізи цих явищ [3].

Друга категорія літератури 3 військової логістики включає доктринальні публікації та посібники - опубліковані в основному військовими організаціями. "NATO Logistics Handbook" та "US Field Manuals" [4, 5] $€$ типовими прикладами цієї категорії. Ці публікації включають доктринальні принципи, правила та інструкції, призначені переважно для командирів та логістів практиків.

Третя категорія публікацій включає в себе дослідження 3 теорії та практики військової логістики. Ці дослідження стосуються суті та структури військової логістики, висвітлюються їі внутрішні властивості, процеси та загальні правила, які регулюють логістику. Останні наукові досягнення та майбутні тенденції у військовій логістиці розкривають ряд грецьких вчених: Василеос Зеймпекис, Джордж Каймакамис, Николас Дж.Дарас та ін. (Vasileios Zeimpekis, George Kaimakamis, Nicholas J. Daras) [6], до науковців з цієї тематики слід віднести також Моше Kресc (Moshe Kress) [3].

Привертають увагу дослідження 3 військової логістики і вітчизняних вчених, таких як: Р. I. Сапіга (2009), В. М. Серватюк, О. I. Угринович (2013), О. М. Маслій (2010), Н. В. Чорнописька, О.В. Брень, О. І.Дангильців (2015), O. I. Ступницький (2014), В. С. Кивлюк, М. Я Клонцак, В. М. Лоза, В.В. Шевченко (2016), О. М. Нестеренко, Ю. Є. Чирва (2016) та інші.

Значний вклад у розвиток теоретичних та практичних засад фармацевтичної логістики України зробили вітчизняні вчені: Б. П. Громовик (2000), О. В. Посилкіна (2004), 3. М. Мнушко (2010), О. П. Гудзенко (2006), Р. В. Сагайдак-Нікітюк (2004), Л. М. Унгурян (2013), В. В. Трохимчук (2007), О. П. Шматенко (2007), С. Г. Убогов (2008), Є. В. Крикавський (2011), А. Г. Хромих (2011), Ю. Є. Новицька (2016) та ін. Натомість, зважаючи на значний науковий доробок, недостатньо опрацьованими лишаються питання щодо трактування терміну “військова логістика" від iii зародження до сучасного визначення у нормативно-правовій базі Збройних Сил України.

Метою роботи стало проведення аналізу існуючих підходів до трактування терміну "військова логістика" в історичному аспекті та дослідження іï сутності у відповідності до сучасних умов функціонування Медичних сил Збройних Сил України.

Матеріали та методи дослідження. Для досягнення мети дослідження проведено аналіз закордонної і вітчизняної наукової літератури та чинної нормативно-правової бази України. Методами дослідження $\epsilon$ інформаційний пошук, порівняння, систематизація, аналіз та синтез.

Результати дослідження та їх обговорення. Аналіз літературних джерел показав, що етимологія поняття “логістика" досі залишається не з'ясованою. Найбільш розповсюдженими є дві версії. За однією з них, воно походить від грецького слова logistikos обчислювати, розмірковувати, за іншою - від французського loger - постачати, розквартировувати. Проте зустрічаються і інші варіанти, зокрема, від давньонімецької laubja склад, зберігання. М. А. Окландер дотримується думки, що семантика поняття "логістика" також неоднозначна. У Стародавній Греції так називали прикладну математику; у Римській імперії - діяльність щодо забезпечення військ продовольством та житлом; у Візантії - процес комплексного вирішення різноманітних проблем, пов'язаних 3 рухом і тиловим забезпеченням армії [7].

Стрімкий розвиток логістики, саме як військової науки, зазначено в багатьох літературних джерелах [8]. Moshe Kress наголошує, що першим логістом був талановитий полководець і політик Олександр Македонський. Саме на логістиці грунтувалася його стратегія і тактика, при найдовшому в історії переході - 4 тис. миль від Єгипту через Персію та Індію. Серед видатних логістів також були не менш видатні воєначальники давнини: карфагенський полководець Ганнібал Барка і римський правитель Гай Юлій Цезар [3].

Візантійський імператор Леон (Leontos) VI (865-912) називав стратегію, тактику i логістику трьома категоріями військового мистецтва. Він писав: “Завдання логістики сплачувати платню армії, належним чином озброювати і розподіляти її, постачати зброю та військове майно, своєчасно і повною мірою турбуватися про іï потреби та відповідно готувати кожний акт військового походу, тобто 
розраховувати простір і час, робити вірний аналіз місцевості з точки зору пересування армії, а також сили опору противника і у відповідності до цих функцій управляти і керувати, одним словом, розпоряджатися рухом і розподілом власних збройних сил" [7].

У тому ж трактуванні термін "логістика" зустрічається в документах Французької королівської армії короля Людовика XIV (16381715). Проте в той же хронологічний період німецький філософ, математик, фізик, мовознавець Готфрід Вільгельм Лейбніц (Leibniz G.V.) (1646-1716) використовує його у значенні математична логіка. Остаточно 3 математичною логікою цей термін ототожнюють після Женевського філософського конгресу (вересень 1904) [7].

Автором перших наукових праць 3 логістики вважають французького військового теоретика Антуана Анрі Жоміні (Jomini А.Н.) (1779-1869 рр.) [9], який служив з 1798 р. у швейцарській армії, з 1804 - у французькій, а з 1813 р. - у російській, під іменем Генріха Веніаміновича в чині генерала від інфантерії. Після узагальнення досвіду Наполеонівських війн, він визначав логістику як мистецтво матеріально-продовольчого забезпечення армії, "міст між економікою нації та діючою армією”. Він також стверджував, що у сферу інтересів логістики входить не тільки перевезення, а й широке коло питань, в тому числі: планування, управління, постачання, визначення місця дислокації військ, будівництва мостів, доріг і т. д. Його праці в кінці XIX століття були видані у США. Там теоретична спадщина А. А. Жоміні знайшла практичне втілення. В роки Другої світової війни вона дозволила організувати стабільне постачання армії за рахунок чіткої координації дій підприємств військово-промислового комплексу, торгівлі, транспорту [7].

Подальший аналіз літературних джерел свідчить про те, що як військова наука логістика сформувалась у середині XIX ст. Широкий розвиток принципи логістики отримали в період Другої світової війни області матеріально-технічного забезпечення американської армії на європейському театрі військових дій. Так, у 1944 р. в Нормандії вітер завадив успішному проведенню військової операції армії союзників під керівництвом Дуайта Ейзенхауера: було порушено зв'язок із Англією, звідки надходили припаси в результаті війська були позбавлені провіанту й амуніції. Таким чином, війська генералів
Ейзенхауера та Монтгомері не могли просуватися вперед, що позначилося на діях армій союзників. Тому логістами Ейзенхауера, 3 метою безперебійного транспортування вантажів, вперше були апробовані прогресивні методи контейнерних перевезень спрямували дорогою Red Ball Express 6 тис. вантажівок. Також були визначені ключові пункти консолідації та розподілу матеріальнотехнічних ресурсів серед військових частин, i союзники змогли успішно завершити операцію. У зв'язку з цим, операція “Ред Болл” (“Червона куля") досі вважається одним із зразків успішної військової логістики $[7,10]$.

На думку Т. А. Репіча (2013) не менше блискучі логістичні операції проводилися в той час і в Радянському Союзі. Так, у перші місяці війни фахівцями Наркомату залізничних колій, у взаємодії 3 іншими профільними відомствами, була проведена евакуація промислових підприємств, що визнано в усьому світі грандіозною та унікальною у своєму роді логістичною операцією. Зокрема, у зв'язку 3 загрозою швидкого наступу німецькофашистських військ, були переміщені за тисячі кілометрів, в т. ч. на Урал і Сибір, сотні промислових підприємств, наукових установ разом із устаткуванням, працівниками та членами їх сімей, а також запасами продовольства, сировини та інші матеріальні ресурси [11].

Таким чином, тільки в часи Другої світової війни принципи логістики почали 3 успіхом втілювати в життя. Зокрема в США, СРСР та інших країнах були проведені дослідження, пов'язані 3 проблемами військового та тилового фронтового постачання, розроблені математичні методи та моделі, які 3 часом отримали назву “дослідження операцій" [7].

Отже, до кінця Другої світової війни термін “логістика" трактувався подвійно: військова логістика - напрямок військової науки, пов'язаний із рухом та постачанням армії; філософська логістика чи математична логіка - напрямок філософії, пов'язаний 3 використанням математичного апарату для доказу дедуктивних тверджень [7].

У даний час, термін "військова логістика" досі перебуває в постійному розвитку і в певні історичні періоди в нього вкладався різний зміст. У таблиці 1 наведено кілька визначень терміну “військова логістика", що належать різним авторам у хронологічному порядку. 
Трактування терміну “військова логістика" в історичному аспекті

\begin{tabular}{|c|c|}
\hline Визначення терміну & Джерело \\
\hline Практичне мистецтво руху військ. & $\begin{array}{l}\text { Антуан Анрі Жоміні (JominiA.) Summary of } \\
\text { the Art of War, } 1838\end{array}$ \\
\hline $\begin{array}{l}\text { Мистецтво керування переміщенням військ, як на } \\
\text { значній відстані, так і поблизу ворога, організація їх } \\
\text { тилового забезпечення. }\end{array}$ & $\begin{array}{l}\text { Военный энциклопедический лексикон - } \\
\text { Санкт-Петербург, } 1850\end{array}$ \\
\hline $\begin{array}{l}\text { Логістика, як третя складова військової науки “стратегія- } \\
\text { тактика-логістика", направлена на те, щоб забезпечити всі } \\
\text { засоби, людські та матеріальні, для ведення війни, } \\
\text { включаючи не тільки традиційні функції постачання і } \\
\text { транспортування, а й військові фінанси, будівництво суден, } \\
\text { виробництво боєприпасів та інші аспекти військової } \\
\text { економіки. }\end{array}$ & $\begin{array}{l}\text { U.S. marine officer, Lieutenant Colonel Cyrus } \\
\text { Thorpe, Pure Logistics, } 1917\end{array}$ \\
\hline $\begin{array}{l}\text { Техніка штабної служби, розрахунки тилів; техніка } \\
\text { перевезень та постачання. }\end{array}$ & $\begin{array}{l}\text { Мюллер В.К. Англо-русский словарь - М.: } \\
\text { Гос. изд-во иностранных и национальных } \\
\text { словарей, } 1963\end{array}$ \\
\hline $\begin{array}{l}\text { Матеріально-технічне забезпечення, робота тилу; } \\
\text { організація тилу та постачання }\end{array}$ & 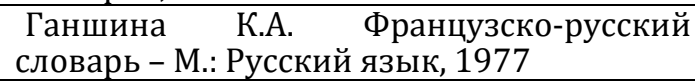 \\
\hline $\begin{array}{lll}\text { Військова } & \text { наука, що пов'язана } 3 \\
\text { підтримкою та рухом матеріалів і людей. }\end{array}$ & $\begin{array}{l}\text { Webster's Desk Dictionary - N-Y.: Portland } \\
\text { House, } 1990\end{array}$ \\
\hline $\begin{array}{l}\text { Управління переміщенням та матеріально-технічним } \\
\text { забезпеченням збройних сил. Разом із тактикою, } \\
\text { стратегією та розвідкою, логістика є одним із чотирьох } \\
\text { найважливіших елементів військової науки. }\end{array}$ & $\begin{array}{l}\text { The Encyclopedia } \\
\text { Internationalo Edition. - Danbury, Grolier } \\
\text { Inc., 1991.V.17 }\end{array}$ \\
\hline $\begin{array}{l}\text { Наука про планування та здійснення пересування } \\
\text { матеріально-технічних засобів, зброї, обмундирування, } \\
\text { харчування, розміщення збройних сил. у найширшому } \\
\text { сенсі, це управління всіма аспектами підготовки та } \\
\text { проведення військових операцій, що включають: } \\
\text { проектування та розробку, придбання, зберігання, } \\
\text { транспортування, розподіл, догляд, евакуацію та } \\
\text { утилізацію матеріалу; перевезення персоналу; придбання } \\
\text { або будівництво, обслуговування, експлуатація та } \\
\text { розташування військових об’єктів; придбання або надання } \\
\text { послуг; організація медичного забезпечення, організація } \\
\text { власне служби логістичної підтримки. }\end{array}$ & $\begin{array}{l}\text { Логистика НАТО - электронный ресурс, - } \\
\text { официальный сайт НАТО, режим доступа: } \\
\text { http://www.nato.int/docu/logi-en/1997/lo- } \\
\text { 103.htm }\end{array}$ \\
\hline $\begin{array}{l}\text { Галузь військової науки та операції, які займаються } \\
\text { закупівлею, постачанням і технічним обслуговуванням } \\
\text { устаткування, } 3 \text { переміщенням, евакуацією, } \\
\text { госпіталізацією персоналу, } 3 \text { наданням об'єктів і } \\
\text { послуг, пов'язаних із цими питаннями. }\end{array}$ & $\begin{array}{l}\text { http://www.dictionary.com/browse/logistic } \\
\text { s }\end{array}$ \\
\hline $\begin{array}{l}\text { Галузь знань } 3 \text { планування, проведення руху та } \\
\text { підтримки збройних сил. }\end{array}$ & $\begin{array}{l}\text { https://en.wikipedia.org/wiki/Military_logis } \\
\text { tics }\end{array}$ \\
\hline $\begin{array}{l}\text { Сукупність засобів і способів, необхідних для доставки } \\
\text { людей, техніки і боєприпасів до місць бойових дій, а } \\
\text { також планування й організація заходів щодо } \\
\text { підготовки і здійснення пов'язаних із цим процесів. }\end{array}$ & $\begin{array}{l}\text { Денисенко М.П., Левковець П.Р., } \\
\text { Михайлова Л.І. та ін. Організація та } \\
\text { проектування } \text { логістичних систем: } \\
\text { Підручник / за ред. проф. М.П. Денисенка, } \\
\text { проф. П.Р. Левковця, проф. Л.І. } \\
\text { Михайлової.- К.: Центр учбової літератури, } \\
\text { 2010. - } 336 \text { с. }\end{array}$ \\
\hline $\begin{array}{l}\text { Вид управлінської діяльності, в основі якої полягає } \\
\text { формування найбільш доцільних умов задоволення } \\
\text { потреб у матеріальних засобах і реалізації цілей } \\
\text { Збройних Сил України шляхом визначення джерела їх } \\
\text { задоволення, виявлення і обліку потреб, їх реальному } \\
\text { впровадженні в процесі науково-дослідницьких і } \\
\text { дослідно-конструкторських робіт та у виробництві, } \\
\text { погодження динамічній відповідності “життєвих } \\
\text { циклів озброєння і військової техніки”, впровадження } \\
\text { руху до кінцевого споживання. }\end{array}$ & $\begin{array}{l}\text { Кивлюк В.С. Вироблення єдиних поглядів } \\
\text { щодо створення сучасної державної } \\
\text { системи логістики Збройних Сил України / } \\
\text { В.С. Кивлюк, М.Я. Клонцак, В.М. Лоза, В.В. } \\
\text { Шевченко // Збірник наукових праць } \\
\text { Військового інституту Кй̈вського } \\
\text { національного університету імені Т. } \\
\text { Шевченка. - 2016. - Вип. 51. - С. 100-109. }\end{array}$ \\
\hline
\end{tabular}


Деякі автори, використовуючи різну термінологію, розглядають однакову суть або явище 3 цієї категорії. Це свідчить про приналежність дослідника до різних логістичних шкіл чи акцентування його уваги на окремих сторонах логістичного процесу або системи в цілому [12-14]. Проте, очевидно, що логістика відіграє вирішальну роль в армії та особливо в часи війни. У своїй авторитетній праці 3 воєнної логістики [1] військовий історик Мартін ван Кревельд (Martin Van Creveld) писав, що логістика - це "практичне вміння переміщати війська і добре їx забезпечувати" [1, 7]. Варто зазначити, що військова логістика також має прямий вплив на зміцнення психологічного, бойового духу військ та об'єднання військових сил (зберігає їх мотивацію та зміцнює моральний авторитет командира) [3].

Як бачимо, проведений аналіз свідчить, що у процесі історичного розвитку наукових підходів ведення військових дій, формувалася і військова логістика. Виникали нові логістичні системи, застосовувалися інноваційні методи та інструменти логістичної підтримки збройних сил [15].

Підсумовуючи існуючі підходи до трактування терміну “військова логістика" та визначення сутності цієї категорії, зазначимо, що логістика $\epsilon$ важливою та невід'ємною частиною бойових дій і вагомою складовою бойового успіху. Військова логістика полегшує рух, захист та підтримку життєздатності збройних сил. Вважаємо за доцільне, посилатися на вислів генерала Роберта Берроу, командувача корпусом морської піхоти США, який підкреслив центральну роль логістики у веденні війни “Стратегія визначає характер i динаміку наших сил, але без логістики стратегічна концепція - це просто паперовий план" [3].

В Україні в останній час набули значущості питання логістичного забезпечення Збройних Сил та інших складових сил оборони України. Пов'язано це із введенням у дію наказу Міністерства оборони України від 11.10.2016 р. № 522 “Про затвердження Основних положень логістичного забезпечення Збройних Сил України". Цим документом концептуально вводиться нове поняття “логістика" (відповідно до STANAG 2406 - “Доктрина 3 матеріально-технічного забезпечення Сухопутних військ НАTO" та офіційно впроваджується поняття "логістичне забезпечення”, яке замінює собою такі поняття, як “тилове і технічне забезпечення", "матеріально-технічне забезпечення".

Відповідно до вищенаведеного наказу, логістика - це наука 3 планування й здійснення переміщення та забезпечення військ (сил), яка застосовується до аспектів військових операцій, пов'язаних із такими видами діяльності:

проектування, розробка (модернізація та модифікація), закупівля, зберігання, транспортування, розподіл, технічне обслуговування i ремонт, евакуація та утилізація МТ3;

транспортування особового складу;

закупівля або будівництво, технічне обслуговування, експлуатація та реалізація військових об'єктів;

закупівля або надання послуг із харчування, лазне-прального обслуговування тощо;

медичне забезпечення.

Згідно з оборонною реформою України, для удосконалення системи управління та наближення іï до принципів і стандартів, прийнятих країнами-членами HATO, в Міністерстві оборони України та Генеральному штабі Збройних Сил України, як подальший етап інтеграції, впроваджено J-структуру - нову систему рівнів військового управління. У зв'язку з цим, створено Головне управління логістики (J-4) у структурі Генерального штабу Збройних Сил України, що дає можливість на стратегічному рівні під єдиним керівництвом здійснювати планування та управління логістичним забезпеченням всіма видами матеріальнотехнічних засобів Збройних Сил України та інших сил оборони, під час виконання спільних завдань. Крім того, 5 лютого 2020 р. відбулося формування нової структури медичної служби згідно 3 J-структурою НАТО, 3 органом управління - Командуванням Медичних сил Збройних Сил України.

Поряд 3 цим, Концепція програми розвитку системи медичного забезпечення Збройних Сил України на період до 2020 року, передбачала передачу функцій медичного постачання до системи логістики Збройних Сил України. Так, на сьогодні забезпечення певною номенклатурою медичного майна віднесено до повноважень Командування Сил Логістики Збройних Сил України.

На наш погляд, на сьогодні вельми актуальним $\epsilon$ формування єдиного логістичного підходу до забезпечення Збройних Сил України медичною технікою та 
майном, враховуючи закріплені у законодавстві правові норми щодо обігу лікарських засобів і медичних виробів та дозвільної системи у сфері фармацевтичної діяльності.

Оскільки управління медичним забезпеченням перебуває у сфері діяльності Командування Медичних сил ЗС України, вбачаємо за доцільне створення єдиноі ефективної системи управління медичним постачанням Збройних Сил України, 3 урахуванням логістичного підходу, під єдиним керівництвом Командувача Медичних сил

\section{Висновки}

1. На підставі проведеного аналізу існуючих підходів до трактування терміну “військова логістика" в історичному аспекті встановлено, що концепція військової логістики $\epsilon$ важливою складовою у плануванні i здійсненні переміщення, забезпечення життєдіяльності військ (сил) у мирний час і особливий період, а також невід'ємною частиною підтримки військових операцій.

2. Досліджено сутність концепції військової логістики у відповідності до сучасних умов функціонування Медичних сил Збройних Сил України та визначено необхідність у формуванні єдиного логістичного підходу до забезпечення Збройних Сил України медичною технікою і майном, 3 урахуванням закріплених у

\section{Література}

1. Martin van Creveld, Supplying War: Logistics from Wallenstein to Patton. 2nd edition. Cambridge University Press, Cambridge Mass, 2004. 313 p.

2. Curley R. The science of War, Strategies, Tactics, and Logistics / edited by Robert Curley, 2011.URL: 1615306633SW.epub.

3. Kress M. Operational Logistics. The Art and Science of Sustaining Military Operations. Second Edition. Springer International Publishing Switzerland. 2016.

URL:https://www.springer.com/gp/book/978331922 $\underline{6736}$.

4. NATO Logistics Handbook. URL: https://www.nato.int/docu/logi-en/logist97.htm

5. United States Army Field Manuals. URL: https://en.wikipedia.org/wiki/

6. Zeimpekis V., Kaimakamis G., Daras N. Military Logistics. 2015.2 URL: https://www.springer.com/gp/book/978331912074 4.

7. Окландер М.А. Логістика: підручник. К.: Центр учбової літератури, 2018. 346 c.

8. Antill Peter. Military Logistics: A Brief History. URL:
Збройних Сил України. Таким чином, інтеграція головних констант військової логістики як у систему військової охорони здоров'я в цілому, так і в її фармацевтичний сектор обумовила створення військово-фармацевтичної логістики у складі медичної логістики Збройних Сил України.

Перспективи подальших досліджень полягають у розробці сучасних підходів і методів, які забезпечують методологічне підгрунтя для формування ефективної системи логістичного забезпечення медичним майном ЗС України.

законодавстві правових норм щодо обігу лікарських засобів і медичних виробів та дозвільної системи у сфері фармацевтичної діяльності.

3. Обгрунтовано доцільність у створенні єдиної ефективної системи управління медичним постачанням Збройних Сил України, враховуючи логістичний підхід, під єдиним керівництвом Командувача Медичних сил Збройних Сил України.

4. Зазначено, що інтеграція головних констант військової логістики, як у систему військової охорони здоров'я в цілому, так і в ії фармацевтичний сектор обумовила створення військово-фармацевтичної логістики у складі медичної логістики Збройних Сил України.

http://www.historyofwar.org/articles/concepts logis tics.html

9. Baron Antoine-Henri De Jomini. The Artof War. Wilder Publications, 2008. 300 p.

10. Колодійчук В. Сутність категорії логістики в економічних дослідженнях. Аграрна економіка. 2014. № 3-4, т.7. С. 99-104.

11.Репіч Т.А. Грандіозні логістичні операції Радянського Союзу. Наукові праці Національного університету харчових технологій. 2013. № 49. С. 202-209.

URL:

http://nbuv.gov.ua/UJRN/Npnukht 20134938

12.Дыбская В.В., Зайцев Е.И., Сергеев В.И., Стерлигова А.Н. Логистика. Полный курс МВА /под ред. В.И. Сергеева. Москва: Эксмо, 2013. 944 с.

13.Кивлюк В.С. Клонцак М.Я., Лоза В.М., Шевченко В.В. Вироблення єдиних поглядів щодо створення сучасної державної системи логістики Збройних Сил України. Збірник наукових праць Військового інституту Київського національного університету імені Т. Шевченка. 2016. Вип. 51. С. 100-109. URL: http://miljournals.knu.ua/index.php/zbirnuk/article/ view/137 
14.Денисенко М.П., Левковець П.Р., Михайлова Л.I. Організація та проектування логістичних систем: підручник. Київ: Центр учбової літератури, 2010. 336 c.

\section{Referenses}

1. Martin van Creveld, Supplying War: Logistics from Wallenstein to Patton. 2nd edition. Cambridge University Press, Cambridge Mass, 2004. 313 p.

2. Curley R. The science of War, Strategies, Tactics, and Logistics / edited by Robert Curley, 2011.URL: 1615306633SW.epub.

3. Kress M. Operational Logistics. The Art and Science of Sustaining Military Operations. Second Edition. Springer International Publishing Switzerland. 2016.

URL:https://www.springer.com/gp/book/978331922 6736.

4. NATO Logistics Handbook. URL: https://www.nato.int/docu/logi-en/logist97.htm

5. United States Army Field Manuals. URL: https://en.wikipedia.org/wiki/

6. Zeimpekis V., Kaimakamis G., Daras N. Military Logistics. $2015 . \quad$ URL: https://www.springer.com/gp/book/978331912074 4.

7. Oklander M.A. Lohistyka: pidruchnyk. K.: Tsentr uchbovoyi literatury, 2018. 346

8. Antill Peter. Military Logistics: A Brief History. URL:

http://www.historyofwar.org/articles/concepts_logis tics.html

9. Baron Antoine-Henri De Jomini. The Artof War. Wilder Publications, 2008. 300 p.

Конфлікт інтересів відсутній.

Conflict of interest: authors have no conflict of interest to declare.

\section{КОНЦЕПЦИЯ ВОЕННОЙ ЛОГИСТИКИ: ОТ ЗАРОЖДЕНИЯ ДО СОВРЕМЕННОГО ТРАКТОВАНИЯ В ВООРУЖЁННЫХ СИЛАХ УКРАИНЫ}

\author{
Т. Н. Остащенко1, А. П. Шматенко², М. В. Белоус², А. В. Галан ${ }^{2}$, Д. В. Дроздов \\ ${ }_{1}^{1}$ Командование Медицинских сил Вооружённых Сил Украины, г. Киев, Украина \\ 2Украинская военно-медицинская академия, г. Киев, Украина
}

Вступление. $B$ настоящее время дальнейший курс развития Украины направлен на евроатлантическую интеграцию. Согласно Государственной программе реформирования и развития Вооружённых Сил Украины на период до 2020 г., была создана единая эффективная система логистики и усовершенствована система медицинского обеспечения Вооруженных Сил Украины в соответствии со стандартами НАТО. Кроме того, осуществлена передача определённых функций медицинского снабжения в систему логистики Вооружённых Сил Украины. Таким образом, вопросы военной логистики сегодня актуальны для Медицинских сил Вооружённых Сил Украины.

Цель работы. Проведение анализа существующих подходов к трактованию термина "военная логистика" в историческом аспекте и исследование её сущности в соответствии с современными условиями функционирования Медицинских сил Вооружённых Сил Украины.

Материалы и методы. Для достижения цели исследования проведен анализ зарубежной и отечественной научной литературы и действующей нормативно-правовой базы Украины. Методами исследования являются информационный поиск, сравнение, систематизация, анализ и синтез. 
Результаты. На основе проведённого анализа установлено, что термин "военная логистика" до сих пор находится в постоянном развитии и в определённые исторические периоды в него вкладывался различный смысл. В процессе эволюции научных подходов ведения военных действий, формировалась и военная логистика. Возникали новые логистические системы, применялись инновационные методы и инструменты логистической поддержки вооружённых сил. В хронологическом порядке дано несколько определений термина “военная логистика". Выяснено, что некоторые авторы, используя различную терминологию, рассматривают одинаковую суть или явление этой категории. Это свидетельствует о принадлежности исследователя к различным логистическим школам или акцентировании его внимания на отдельных сторонах логистического процесса или системы в целом.

Выводы. На основании проведённого анализа существующих подходов к трактованию термина “военная логистика" в историческом аспекте установлено, что концепция военной логистики является важной составляющей в планировании и осуществлении перемещения, обеспечения жизнедеятельности войск (сил) в мирное время и особый период, а также неотъемлемой частью поддержки военных операций. Исследована сущность конщепции военной логистики в соответствии с современными условиями функционирования Медицинских сил Вооруженных Сил Украины. Определена необходимость в Формировании единого логистического подхода к обеспечению Вооруженных Сил Украины медицинской техникой и имуществом, с учетом закреплённых в законодательстве правовых норм относительно обращения лекарственных средств и медицинских изделий, а также разрешительной системы в сфере фармацевтической деятельности. Обоснована целесообразность в создании единой эффективной системы управления медицинским снабжением Вооруженных Сил Украины, учитывая логистический подход, под единым руководством Командующего Медицинских сил Вооруженных Сил Украины. Отмечено, что интеграция главных констант военной логистики, как в систему военного здравоохранения в целом, так и в её фармацевтический сектор, обусловила создание военно-фармацевтической логистики в составе медицинской логистики Вооруженных Сил Украины.

Ключевые слова: военная логистика, Медицинские силы Вооружённых Сил Украины.

\title{
THE CONCEPT OF MILITARY LOGISTICS: FROM BIRTH TO MODERN INTERPRETATION IN THE ARMED FORCES OF UKRAINE
}

\author{
T.M. Ostashchenko1, O.P. Shmatenko², M.V. Bilous ${ }^{2}$, O.V. Galan², D.V. Drozdov ${ }^{2}$
}

\author{
${ }^{1}$ Medical Forces Command of the Armed Forces of Ukraine, Kyiv, Ukraine \\ ${ }^{2}$ Ukrainian Military Medical Academy, Kyiv, Ukraine
}

Introduction. At present, the further course of Ukraine's development is aimed at Euro-Atlantic integration. According to the State Program for Reforming and Development of the Armed Forces of Ukraine for the period up to 2020, a unified efficient logistics system was created and the medical support system of the Armed Forces of Ukraine was improved in accordance with NATO standards. In addition, certain functions of medical supplies were transferred to the logistics system of the Armed Forces of Ukraine. Thus, the issues of military logistics are relevant today for the Medical Forces of the Armed Forces of Ukraine.

The purpose. Analyzing the existing approaches to the interpretation of the term "military logistics" in the historical aspect and researching its essence in accordance with the modern conditions of functioning the Medical Forces of the Armed Forces of Ukraine.

Materials and methods. To achieve the goal of the research, an analysis of foreign and domestic scientific literature and the current regulatory framework of Ukraine was carried out. Research methods are information retrieval, comparison, systematization, analysis and synthesis.

Results. Based on the analysis, it has been established that the term "military logistics" is still in constant development and in a certain historical period. In the process of evolution of scientific approaches to the conduct of military operations, military logistics was also formed. And new logistics systems emerged, innovative methods and tools were used to support the armed forces. Several definitions of the term "military logistics" are given in chronological order. It was found that some authors, using different terminology, consider the same essence or phenomenon of this category. This indicates that the researcher belongs to various logistics schools or focuses his attention on certain aspects of the logistics process or the system as a whole.

Conclusions. Based on the analysis of existing approaches to the interpretation of the term "military logistics" in the historical aspect, it was determined that the concept of military logistics is an important component in planning and implementing the movement, ensuring the vital activity of troops (forces) in peacetime and a special period, as well as integral part of supporting military operations. The essence of the concept of military logistics is investigated in accordance with the modern conditions of the functioning of the Medical Forces of the Armed Forces of Ukraine. The need for the formation of a unified logistic approach to the provision of the Armed Forces of Ukraine with medical equipment and property is determined, taking into account the legal norms established in the legislation regarding the circulation of medicines and medical devices, as well as the licensing system in the field of pharmaceutical activities. The expediency of creating a unified effective medical supply management system of the Armed Forces of Ukraine, taking into account the logistic approach, under the unified leadership of the Commander of the Medical 
Forces of the Armed Forces of Ukraine has been substantiated. It is noted that the integration of the main constants of military logistics, both in the military health care system as a whole and in its pharmaceutical sector, led to the creation of military pharmaceutical logistics as part of the medical logistics of the Armed Forces of Ukraine.

Key words: military logistics, Medical Forces of the Armed Forces of Ukraine.

\section{Відомості про авторів:}

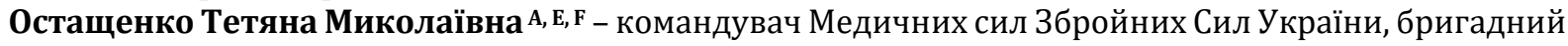
генерал медичної служби, м. Київ, Україна.

Шматенко Олександр Петрович А, в - доктор фармацевтичних наук, професор, заслужений працівник фармації України, полковник медичної служби, начальник кафедри військової фармації, Українська військово-медична академія, м. Київ, Україна. Email: mavad@ukr.net; ORCID: https://orcid.org/0000-0002-6145-460X

Білоус Марія Вікторівна A, в, с, D - доктор фармацевтичних наук, доцент, професор кафедри військової фармації, Українська військово-медична академія, м. Київ, Україна. Email: maryvictory@ukr/net; ORCID: https://orcid.org/0000-0002-4370-8813

Галан Олександр Валентинович C, E - старший викладач кафедри військової фармації, заслужений працівник фармації України, полковник медичної служби у відставці, Українська військово-медична академія, м. Київ, Україна. E-mail: galan1968@ukr.net. ORCID: https://orcid.org/0000-0002-0005-5699

Дроздов Дмитро Вікторович в, с - кандидат фармацевтичних наук, доцент кафедри військової фармації, Українська військово-медична академія, м. Київ, Україна. ORCID: https://orcid.org/0000-00027769-750X

$A$ - концепція та дизайн дослідження; $B$ - збір даних; $C$ - аналіз та інтерпретація даних;

$D$ - написання статmi; E - редагування статmі; F- остаточне затвердження статті.

\section{Сведения об авторах:}

Остащенко Т.Н. - командующая Медицинскими силами Вооружённых Сил Украины, бригадный генерал медицинской службы.

Шматенко А.П. - доктор фармацевтических наук, профессор, заслуженный работник фармации Украины, полковник медицинской службы, начальник кафедры военной фармации, Украинская военномедицинская академия, Киев, Украина.

Белоус М.В. - доктор фармацевтических наук, доцент, профессор кафедры военной фармации, Украинская военно-медицинская академия, г. Киев, Украина.

Галан А.В. - старший преподаватель кафедры военной фармации, заслуженный работник фармации Украины, полковник медицинской службы в отставке, Украинская военно-медицинская академия. E-mail: galan1968@ukr.net. ORCID: https://orcid.org/0000-0002-0005-5699

Дроздов Д.В. - кандидат фармацевтических наук, доцент кафедры военной фармации, Украинская военно-медицинская академия, Киев, Украина.

Information about authors:

Ostashchenko Tetiana - Commander of Medical Forces of Armed Forces of Ukraine, Brigadier General of the Medical Service, Kyiv, Ukraine

Shmatenko Olexandr - DSc (Pharmacy), Professor, the Honoured Employee of Pharmacy of Ukraine, colonel of Medical Service, head of the Department of Military Pharmacy, Ukrainian Military Medical Academy, Kyiv, Ukraine, Email: mavad@ukr.net; ORCID: https://orcid.org/0000-0002-6145-460X

Bilous Mariia - DSc (Pharmacy), professor of the Department of Military Pharmacy, Ukrainian Military Medical Academy, Kyiv, Ukraine, E-mail: maryvictory@ukr.net. ORCID: https://orcid.org/0000-0002-4370-8813.

Galan Olexandr - senior lecturer of Department of Military Pharmacy, Honored Pharmacist of Ukraine, Ukrainian Military Medical Academy, Kyiv, Ukraine, E-mail: galan1968@ukr.net. ORCID: https://orcid.org/00000002-0005-5699

Drozdov Dmitry - PhD, (Pharmacy), associate professor of Department of Military Pharmacy, Ukrainian Military Medical Academy, Kyiv, Ukraine, ORCID: https://orcid.org/0000-0002-7769-750X

Адреса для листування: вул. Московська, 45/1, буд. 33, м. Київ, 01015. 